\title{
Posterior Tongue Adenoid Cystic
}

\section{Carcinoma}

National Cancer Institute

\section{Source}

National Cancer Institute. Posterior Tongue Adenoid Cystic Carcinoma. NCI Thesaurus.

Code C5991.

An adenoid cystic carcinoma arising from the minor salivary glands in the base of the tongue. 